and its development and application in practice occupies the bulk of the book.

This is not a book for the average reader, and even the specialist in personnel management and efficiency ratings will have some difficulties following the statistical theory involved. Nevertheless, it is an important contribution. Its chief weakness lies in the generalizations of personal experience and limited experiments. Hence the basis for comparison in this, as in most employee rating schemes, is the judgment of the supervisors. The experimentation used to develop the rating scheme can hardly be said to meet all the requirements of Professor Ryan's scientific method. Nevertheless, the Probst scheme is one of the better rating schemes and the book should be of interest to specialists in the field of efficiency ratings.

Mr. Young's contribution is a peppy exposé of what he calls "the newest profession." Its style, choice of language, and presentation is intended to appeal to the busy businessman and will. The "newest profession," as the author terms human engineering, covers the relationship of human engineering to the quality of supervision and profits, instructions, human relations, motivation, improved methods and similar problems. Chapters such as "A Magic Formula," "Some Soul Searching," and "Happier and Healthier," indicate that the general function of the book is the promotional side rather than the psychological re- search side. Nevertheless, the book should stimulate average business and supervisory personnel to a more active approach to the principles enunciated by people like Roethlisberger, Dickson, Whitehead, and now Ryan. While the intellectual content is probably considerably less than that of either of the other two books reviewed, the book is much more easily readable and will probably be read by many more people.

Incidentally, the magic formula is " $\mathrm{He}$ who would be a leader of men must first master himself and serve others." The chart for self-examination on pages $94-95$ indicates a rather subjective approach. This doesn't prove that either Ryan's objectivity or Young's subject approaches is wholly right or wrong. Rather it does indicate the fundamental difference between this book and the one by Ryan.

The philosophy of J.M.T. and J.R.T., and J.I.T. is covered in the chapter on improving methods. Chapter 13 explains human nature in 24 pages.

The book has a very good bibliography on pages I9I-195, and what is more unusual, an excellent list of visual aids on pages 197-202. Though of the Dale Carnegie school rather than the Ryan school, this book should be stimulating reading for the nonspecialist in human relations or psychology.-Ralph $R$. Shaw, librarian, U.S. Department of Agriculture.

\title{
Buildings for Service
}

Library Buildings for Library Service. Edited, with an introduction, by Herman H. Fussler. Chicago, American Library Association, 1947. xiv, 2I6p.

Library Buildings for Library Service is a product of the institute devoted to the planning and construction of library buildings at the University of Chicago in August 1946. It deals systematically and topically with the issues met by librarians, governing bodies, and architects as they grapple with the task of providing new quarters for libraries. It seeks to treat its subject in the light of currently available knowledge and in ways helpful to libraries of various types.

The volume embraces twelve papers, which collectively undertake to set forth the historic evolution of library buildings, the functions and contents they must accommodate, the processes entailed in a building project, the roles of the parties concerned in such an enterprise, the technical matters which relate to lighting and the treatment of air, and the possibilities opened by new building materials and changed methods of fabrication. Seven of them come from the pens of librarians who have enjoyed generous experience or observation in matters relating to the administration and/or the housing of libraries. The others were written by architects and engineers, and contribute expert information of kinds which librarians ordinarily do not possess.

The notes which are dominant in Library Buildings for Library Service are by no means new, but they deserve the emphases they receive in the book because they so seldom gain 
complete acceptance and application in practice. Architects have subscribed to functionalism for a good many years; and the principle probably has been axiomatic with librarians even longer, even though they may have had difficulty in formulating it and may barely have been conscious of it. Similarly, flexibility has been striven for more or less intelligently in various buildings, including libraries, its advantages presumably having been seen by both designers and occupants. That these ideas should have been played upon repeatedly by speakers at the institute seems encouraging, since their general adoption may depend upon just such exploitation.

The proper division of labor on a building project possibly has not been recognized as generally as have functionalism in plan and flexibility in construction, but its logic is so obvious that the kind of stress placed upon it at the institute should go far to establish it. To be sure, some verbal differences appeared as to just what the librarian should furnish to the architect, in order that the architectural solution of a given problem may proceed and eventuate fruitfully. There was no doubt that he should present the purposes and specific needs of his institution, however, making the requirements so clear and so unmistakable that no interpreter could escape them, be he ever so unlearned in the lore and the operations of libraries. Foresight, planning, hard work, and the willingness to carry his fit responsibility are involved here for the librarian. As the author of one paper pointed out, willingness and capacity to couch his statements in language which nonlibrarians can understand.

The technical papers may prove to vary somewhat in their value. There is much in the treatment of lighting that links up readily with the knowledge and experience of those who operate or work in libraries. It should help in the avoidance of mistakes, and perhaps pave the way for the further education of librarians in a complex and developing field. Perhaps the same can be said about the chapter on the treatment of air, but parts of it may be found difficult going for those who do not have occasion to think daily in terms of dew-point temperature, latent heat, evaporative cooling, and hygroscopic solutions.

As is pointed out in the papers themselves, the discussions are timely because building problems are much in librarians' minds. Before all the buildings now contemplated are under way, it of course is possible that some of the views and data in Library Buildings for Library Service may be outdated and have to be supplemented or superseded. But here is a presently valuable collection of information and viewpoints, essential reading for all who currently face building problems. It represents an important layer in the knowledge and experience regarding the housing of libraries which are being accumulated.-Ernest J. Reece, School of Library Service, Columbia University.

\section{Graduate Work and Research in the South}

Graduate Work in the South. By Mary Bynum Pierson. Chapel Hill, University of North Carolina Press, 1947. Published under the sponsorship of the Conference of Deans of Southern Graduate Schools. $265 \mathrm{p}$.

The Graduate School: Research and Publications. Edited by Edgar W. Knight and Agatha Boyd Adams. Chapel Hill, University of North Carolina Press, 1946. (University of North Carolina Sesquicentennial Publications.) 46 ip.

The Graduate School: Dissertations and Theses. Edited by James L. Godfrey, Fletcher M. Green, and W. W. Pierson. Chapel Hill, University of North Carolina
Press, 1947. (University of North Carolina Sesquicentennial Publications.) I84p. Dr. Mary Bynum Pierson's work is the first full-length treatise on graduate work in the South. The professional writings, already voluminous, consist largely of official printed reports, convention proceedings, and articles in professional magazines. Among these contributions are a few, such as the Pierson (W.F.) and Pipkin reports, which deserve the name of studies, as well as books and chapters in books by librarians which appraise the research resources of libraries in the Southern states. The time had come for a comprehensive treatment of the historical setting and problems of graduate work in 